UDC 81

DOI https://doi.org/10.32838/2710-4656/2021.3-1/38

Hasanova K. K.

Institute of Linguistics named after Nasimi of Azerbaijan National Academy of Sciences

\title{
SOME ETHNOTOPONYMS OF TURKIC ORIGIN \\ BELONGING TO DEMIRCHIHASANLI DISTRICT IN THE "COMPREHENSIVE BOOK OF TBILISI PROVINCE"
}

It is impossible to find a person, country, mountain, river, city, village, street without a special name. The whole nation participates in the creation of names individually. These names are derived from life, human desires, and human thinking. That is why our historical past and present life, desires and aspirations are in harmony with the names. It is our duty to reveal them. It should also be noted that as life develops, small settlements grow into villages, and villages over time become settlements and cities, and tribal and tribal alliances become large states. All this is sealed under special names. One of the sources where these names are stamped is the "Detailed Book of Tbilisi Province". The "Book..." is a historical document written at a time when it played a decisive role in the formation of the Azerbaijani people. It is also clear from this document that at that time (early 18th century, 1728) Azerbaijan had a strong system of feudal statehood. Each of the onomastic units in the "Book..." separately contains the names of our people related to more ancient times, as well as facts related to the economic development, socio-political, national-cultural spirituality, agriculture, crafts, household culture of that period. The names of the toponyms here correspond to the principle of the ancient Turkish-Azerbaijani toponymic tradition. Many toponymic units of Azerbaijani origin have been recorded in many sources on the history, culture and folklore of the Azerbaijani people. Ancient written monuments, folklore and cultural monuments of our people are rich in toponymic facts. Their research and analysis helps to reveal issues related to the historical thinking and social conditions of the people. One of the important issues is the study and involvement of the Azerbaijani language, in general, the cultural traces of the Turkic languages in the history and territory of other nations. It should be noted that the study of toponyms is of special importance in the study of the history of tribes, clans and peoples. Due to various socio-political events, different tribes named their new settlements in their native language. Traces of history are preserved in these names. From this point of view, the names of tribes and clans should be studied in connection with the territory and history of other states. We consider it expedient to give a detailed explanation of some historically existing toponymic names in this book.

Key words: Tbilisi province, detailed book, ethnotoponym, Sirajli, Sofulu, Kapanakchi, etymological analysis.

Introduction. At present, the study of toponyms of Turkish origin is of great importance. Toponymic units, especially ethnotoponyms of Turkish origin, are considered a valuable source in the history of language. Traces of history remain in toponyms. Therefore, the most important thing is to look for these historical traces [9, p. 38]. It should be noted that recently our toponymic names have been Armenianized and falsified. Ethnonymic units name human settlements belonging to Azerbaijan with reference to some fake materials. Extralinguistic factors are valuable evidence of the historical truths they carry, historical information, and the place of settlement of the people. In general, each language is based on national language units. These units are formed in connection with the history of the people, gain rights and live in the language $[9$, p. 260]. When analyzing the written monuments and other materials of the Turkic peoples, the history of most units of Turkish origin, especially onomastic units, goes back a long way. The nationality and antiquity of these names are especially prominent, the main part of the onomastic system consists of national special names created in accordance with the rules of our language.

Purpose and tasks of the research. To reveal toponymic names of Turkish origin registered in the "Comprehensive Book of Tbilisi Province" and to give a broad etymological analysis of them.

Scientific novelty of research. Although ethnoponyms of Turkish origin have been extensively studied by scholars, ethnotoponyms of Turkish origin recorded in the "Comprehensive Book of Tbilisi Province" have been thoroughly studied for the first time. 
Methods and sources of research. The issues raised in advance determine the methods of their resolution and verification. Historical-comparative and comparative-contrastive methods are used. As a source, historical and modern terminological dictionaries are used, especially dictionaries related to linguistic terminology.

A review of recent research and publications. "Encyclopedic dictionary of toponyms of Azerbaijan"; "Toponyms of Turkic origin of the Caucasus" by T. Bakhshiyeva; "Toponyms of Kitabi Dada Gorgud and Caucasus area" by A. Bayramov; "Toponyms of Turkic origin of Western Azerbaijan Baku" by I. Bayramov; "Explanatory dictionary of toponyms of Azerbaijani origin in Armenia" by B. A. Budagov, Q. A. Geybullayev; "Borchali toponyms" by M. Chobanov, M. Borchali; "Historical geography of Armenian Azerbaijanis"; "Keys of talismans in the 40th room" by X. Aliyev (toponyms of Borchali, Akhisga, Gazakh); "Basics of Azerbaijan onomology" by A. Gurbanov; "Book-history - Karabakh" by Mir Mehdi Khazani; "Karabakh-letters"; "Detailed book of Tbilisi province" (Borchali and Gazakh) and other electronic sources were used during analyze of the topics.

Presentation of the main material. The importance of toponymic units in the "Comprehensive Book of Tbilisi Province" in the study of toponyms of Turkish origin is undeniable. From this point of view, we consider it expedient to analyze the etymology of some toponyms mentioned in the "Book...". Most of the onomastic units here are toponyms, anthropoponyms and ethnotoponyms of Turkish origin. Different Turkic languages participated in the formation of these onomastic units at different times. When studying the toponyms of Turkish origin mentioned here, it is important to determine their phonetic, lexical-semantic features and areas. Any toponymic name must be written as it is, without distortion. When adapting the toponym to the literary language, the idiom of the local people should be indicated in parentheses [8, p. 101]. "Book..." also includes historical events related to various fields of ethnographic, agricultural, cattle-breeding, art culture of the Azerbaijani people, toponyms of geographical landscape, names of different historical figures, generations, tribes and clans and their parallels in different areas is reflected [8, p. 100-101].

Each area toponymic unit reflects the linguistic features of the period of its formation [2, p. 184]. The same name can be found in different sources. This shows that the ancient Turkic people settled in large areas. It is also due to the fact that these Turkic tribes are connected by the same roots and mix with each other. Of course, it is a bit difficult to say which is the original variant of toponyms that differ from the phonetic point of view.

The etymological analysis of the toponyms mentioned in the "Book..." will give a clearer picture of their language. Garachibashi winter camp, Yuzbashi community, Telli neighborhood, Chubuglu winter village, Uruz winter village of Yuzbashi tribe, Garatikanli Kapanakchi tribe, Gypsy community, Sinigkorpu, Sanli glass, Baysan, near Sarvan glass, Baylija near the Demirchihasanli district mentioned here community, Saracli, Gajarli, Nazarli, Sofulu community, Kosali community, Petekli winter camp, Calli community, Garadamirchi winter camp, Chomaglibulag field, Tap field, Gushgonan field, Calagli, Kolagir, Solagu, Kolagir villages of Baratli district Let's look at the etymological analysis of some toponyms of Turkish origin, such as Shishtepe, Selcikli, Sarajli, Tazali winter.

Sirajli(Sarajli)ethnotoponymisoneofthetoponyms subordinated to Demirchihasanli district in the "Comprehensive Book of Tbilisi Province" [11, p. 92]. According to the sources, the Kipchak-Kazakh Karapapaks are named after the Sarajli people belonging to the Gazakh people. "Sarajli" was formed on the basis of the tribal name [6, p. 188]. In the Middle Ages, one of the tribes in the Ottoman Empire was Sarajli. The oldest official document about the village of Sarachli is the Tsar's "Programming", which is still preserved in three versions in Georgian museums. Compiled during the reign of George XI (1682-1688) and later added, the word "village" in the two versions of these documents - Sulkhan Mdivani and Alexi Meshkhishvili - is derived from the Arabic word for "information" and means "information" sopeli ("Saraclu village of Emin province"). Some Georgian clerks used the word "sopeli" to describe local settlements, and nomadic villages were called "oba" [12]. So, Georgian historical sources have considered Sarachli a settled village since the end of the 17th century. Until the end of the 18th century, the Sarach people lived in the Demirchihasanli district (now Gardabani region) on the left bank of the Kura River.

At present, Saracli people are mentioned among the tribes spread in different regions of Turkey. According to the locals, at one time this plain (in Sharur district) was from Saraj branch plain. What is the meaning of the words "Saraj" and "branch" in the origin of this toponym? According to the locals, the name of one of the 90 families of a tribe of Kazakhs is Sarashli, which was once the territory of the Sarajli dynasty [8, p. 220]. Sarajli is also men- 
tioned as a pasture in Loru-Pembek district of Tbilisi province, now in Kalinino district. It is located in Jujakend (Golden Dawn) village of the region. The oronym is based on the name of the Sarijali Turkic tribe [10, p. 104-105]. So, Sarajli Sarijali is a simple ethno-oronym, which is a phonetic form of the name of the Turkic tribe. In another source, the toponym Sarajli is mentioned as a simple oykonim in the form Sarijali. Here are the settlements of Sarija, Sarija plain, Sarijalar, Sarijali Sheki region; Sarija plain, Sarijalar is marked as a settlement in Saatli region. Mugan is on the plain. His real name is Sarijali. Later it was distorted and became Sarichalar. The settlement was formed as a result of the settlement of the Sarijali (actually Sarijalili) branch of the Javanshir tribe. It is given as two villages in Aghdam region: 1) in the Karabakh plain it is in Aghdamkend region of Aghdam region. His full name was Dargahli Sarijali; 2) Chamenli Sarijalisi in the foothills of the Chamenli area of the Aghdam region. In addition, the toponym sarijali was given as a village name in Agjabadi district, Shukurbayli area of Jabrayil district (Gayan cholu), Sahlabad area of Tartar district (full name Yetim sarijali). The names of these settlements are connected with the name of Sarijali, a branch of Bahmanli [1, p. 175].

The sources give us reason to say that the toponym Sarajli is a toponym of Turkish origin, the lexical unit was initially developed in the form Sarijali and then as a result of phonetic change of the word Sarajli, Sarachli, Sirajli, Saraj, Sarichali, Sarajlilar, Sarijalilar, Sarija.

Sofulu, one of the toponyms of Turkish origin in the "Book...", is explained in different ways in the sources. It is noted that the name of the village in Boyahmedli i.a.v of Sofulu Aghdam region is an ethno-economic name formed as a result of settlement of the tribe of the same name living in Karabakh. It is also mentioned as the name of the village in Jafarli administrative district of Gazakh region (again under the name of Sofulu tribe), in Dag Tumas administrative district of Jabrayil region, at the foot of Karabakh range. This tribe began to lead a nomadic lifestyle and later a sedentary lifestyle in Azerbaijan. For this reason, the village of Sofulu was formed [1, p. 193]. It is the name of a village in Zangazur district of Yelizavetpol (Ganja) province, present-day Sisiyan region. It is located $18 \mathrm{~km}$ south-west of the district center. Only Azerbaijanis lived in the village. In 1959 alone, 1816 Azerbaijanis lived here [7, p. 190]. In November 1988, Azerbaijanis were expelled from the area. At present, Armenians live in the area. It is a simple ethnotoponym by structure. The name of the village was distorted into Soflu [4, p. 261]. The Sophular oykonim mentioned in some sources is also connected with the name of the Sofulu tribe.

The fact that the representatives of the Sofulu tribe settled mainly in Gazakh and Zangazur districts also shows that it is a toponym of Turkish origin. Gorgud scholar Aslan Bayramov tried to reveal the etymological meaning of the word Sofulu in his book "Toponyms of Kitabi Dada Gorgud and the Caucasian area". When explaining the word Sofulu, the author equates it with the word Sufi. Although the word is of Greek origin, it was translated into Azerbaijani and Turkish through Arabic. In the first sense it means religious, ascetic, Muslim, in the second sense - hypocritical, hypocritical [3, p. 373]. It is not correct to connect this toponym with Sufism. Because Sufism is a religious movement that spread in Iraq and Syria in the VIII century, and in Azerbaijan in the 9th-10th centuries. The Sufis, on the other hand, came from Central Asia in the 5th century as a branch of the great Kangarli (Gangarli) tribe before Islam and settled in the Caucasus, especially in Azerbaijan. For this reason, the toponym sofulu is considered to be of Greek or Arabic origin and should not be equated with the word Sufi. It is sometimes found in the sense of "sofulu". But a large tribe could not take that name. The etymological meaning of each word and the source on which we base our interpretation of that meaning sometimes lead to a misinterpretation of that word, leading to the wrong conclusion. The word Sofulu is also a Turkish word (from the word "sofi") and means the name of a tribe, being an ancient ethnos. "Religious", "ascetic", "a person who does not deviate from religious doctrines" means "Muslim". Like other tribal names, sofulu is a tribal name.

Alavar is the name of a village in Borchali district of Tbilisi province (now in Gugar region of Armenia). In Turkish, the regiment consists of the words "military unit" and "there". In toponyms, the word "var" means both "get up" and "side" in Iranian languages, and "camp site" in the Azerbaijani language in the 19th century. In the 17th century, Alaber was recorded as the name of a village in the Armenian script in Kotak (later Darachichek) district of Iravan district, which has the same meaning as the name of the village [5, p. 117].

Qamishgut - name of the village in Borchali district of Tbilisi province. Now it is the name of a village in the Gugar region of Armenia. In the middle of the 19th century, Armenians from Turkey settled in the village. According to the information, in 1887 the population of the village was Armenian. 
At the end of the 20th century, some Azerbaijanis returned and lived mixed with Armenians. In 1919, the Azerbaijani population was expelled and Armenians from Turkey were resettled. In 1935, the Armenian village was renamed Yehegnut. The Azerbaijani reed and Mongolian khot consist of the words "camp" or "gut" [5, p. 117].

Kapanakchi, mentioned in the "Comprehensive Book of Tbilisi Province", is one of the largest tribes in the "Demirchihasanli" district in the "Book". Thus, many tribes, winters and villages are united here. Ilkhichi Yusif, Kathudali, Haji Saleh, Jafar, Abulgasim, Chatal Veli, Haji oglu, Dever, Garaokuz, Mohammad winter camps, Ahmad (34 people), Jarchi (14), Veli, Muganli (31) communities and neighborhoods were subordinated to this area [11, p. 69-75]. The word "kapanak" is used in the epics "Dada Gorgud" and "Koroglu" to mean "maker". Later, the word Kapanakchi was formed by combining the suffix -chi, which means art and occupation. The general meaning is a tribe engaged in the profession of making salman (while making) [6, p. 181]. Thus, the tribe and the village where they lived got their name from the word "butterfly", which is the name of their profession. The ethno-toponym Kapanakchi was created on the basis of this word. It is the name of a mountain in Alexandropol district of Iravan province, in the present-day Duzkend (Akhuryan) region. It is now the village of Bolnis-Kapanakchi. At present, there is a village called Kurustu Kapanakchi in Marnueli district and Kapanakchi in Zakatala district. In the territory of the former Iravan province there were Boyuk Kapanakchi and Kichik Kapanakchi villages, which were later renamed.

Conclusions. In any language, a name is associated with a distinctive sign. It is impossible to imagine human society without names. People, animate and inanimate beings, historical events, the names of the year, the moon, celestial bodies, and geographical objects are all distinguished by their names. In linguistics, all these special names are called onomastics, and special names are called onomastic units. The history, origin, phonetic, lexical-semantic and grammatical features of onomastic units in language are clarified by etymological analysis. As a result of the development of society, language also develops. In the process of this development, the ancient words in the language can change their form and content and create new shades of meaning. Such changes are more easily identified with the help of onomastic sources. From this point of view, the etymological analysis of onomastic units of Turkish origin registered in the "Comprehensive Book of Tbilisi Province" is also important.

\section{References:}

1. Encyclopedic dictionary of toponyms of Azerbaijan : in 2 vol. Baku : East-West, 2007. Vol. 2. 303 p.

2. Bakhshiyeva T. Toponyms of Turkic origin of the Caucasus. Baku, 2010. 255 p.

3. Bayramov A. Toponyms of Kitabi Dada Gorgud and Caucasus area. Baku, 2007.

4. Bayramov I. Toponyms of Turkic origin of Western Azerbaijan. Baku : Science, 2002. 346 p.

5. Budagov B. A., Geybullayev Q. A. Explanatory dictionary of toponyms of Azerbaijani origin in Armenia. Baku : Oguz eli, 1998. 385 p.

6. Çobanov M., Borchali M. Borchali toponyms. Baku, 2012. 356 p.

7. Historical geography of Armenian Azerbaijanis. Baku : Youth, 1995. 464 p.

8. Aliyev X. Keys of talismans in the 40th room (toponyms of Borchali, Akhisga, Gazakh). Ganja : Elm, 2008. $300 \mathrm{p}$.

9. Gurbanov A. Basics of Azerbaijan onomology : in 2 vol. Baku, 2019. Vol. 1. 280 p.

10. Mir Mehdi Khazani. Book-history - Karabakh : in 2 vol. Baku : Writer, 1991. Vol. 2 : Karabakh-letters. $202 \mathrm{p}$.

11. Detailed book of Tbilisi province (Borchali and Gazakh). Baku : Pedagogy, 2001. 256 p.

12. Qədim SARAÇLI kəndi. URL: http://zim.az/bolnisi/780-qdim-sarali-knd.html.

\section{ГасаНова К. К. ДЕЯКІ ЕТНОТОПОНІМИ ТЮРКСЬКОГО ПОХОДЖЕННЯ, ПІДПОРЯДКОВАНІ РАЙОНУ ДЕМІРЧІХАСАНЛІ, У «ДЕТАЛЬНІЙ КНИЗІ ПРОВІНЦІЇ ТБІЛІСІ»}

Без спеціальної назви неможливо знайти людину, краӥну, гору, річку, місто, село, вулицю. Увесь народ бере участь у створенні імен індивідуально. Ці імена мають своїм джерелом життя, людські бажання та людське мислення. Ось чому наше історичне минуле та теперішнє життя, бажання і прагнення узгоджуються з іменами. Наш обов'язок - розкрити їх. Варто також зазначити, що з розвитком життя маленькі поселення переростають у села, а села із часом стають поселеннями та містами, племінні союзи і союзи племен - великими державами. Усе це закріплено спеціальними назвами. Одним із джерел, де ці імена представлені, є "Детальна книга провінції 
Тбілісі». «Книга...»- - ее історичний документ, написаний у той час, коли він зіграв вирішальну роль у формуванні азербайджанського народу. Із иього документа також видно, що на той час (початок 18 століття, 1728 р.) в Азербайджані існувала потужна система феодальної державності. Кожна з ономастичних одиниць у «Книзі...» містить окремо імена наших людей, які проживали в більш давні часи, а також факти, пов 'язані з економічним розвитком, соціально-політичною, національнокультурною ситуачією, сільським господарством, ремеслами, побутовою культурою иього періоду. Назви топонімів у книзі відповідають принципу давньої турецько-азербайджанської топонімічної традииї. Багато топонімічних одинищь азербайджсанського походження зафіксовані в багатьох джерелах про історію, культуру та фольклор азербайджанського народу. Давні писемні пам'ятки, фольклор і пам'ятки культури нашого народу багаті на топонімічні факти. Дослідження їх дає змогу розкрити проблеми, пов'язані з історичним мисленням та соиіальними умовами життя людей. Одним із важливих питань є вивчення азербайджанської мови, ї̈ залучення в життя, аналіз культурних слідів тюркських мов в історії та бутті інших народів. Варто зазначити, щзо вивчення топонімів має особливе значення у процесі дослідження історії племен, родів і народів. Через різні суспільно-політичні події різні племена називали свої нові поселення рідною мовою. У цих назвах збереглися сліди історії. Із иієї позицї назви племен і кланів варто вивчати у зв'язку з територією та історією інших держав. Ми вважаємо за дочільне детально пояснити деякі історично існуючі в иіий книзі топонімічні назви.

Ключові слова: Тбіліська губернія, детальна книга, етнотопонім, Сірайлі, Софулу, Капанакчі, етимологічний аналіз. 